\title{
FRONTIERS OF EXCLUSION IN EDUCATIONAL OPPORTUNITIES AND INCLUSIVE EDUCATION SYSTEM
}

\author{
H.M.D.S. Herath \\ School of Social Work, National Institute of Social Development, Sri Lanka
}

\begin{abstract}
Schools are main public spaces for social development and they provide formative education to students as a secondary social institution throughout the world. Social exclusion and unequal educational opportunities are growing phenomenon in both developed and under developed countries. Inclusive education ensures equal education opportunities for visually, physically and financially handicapped children regardless of their inabilities, class or caste. The national education policy of Sri Lanka comprises a special section on implementing inclusive education policy within the country but many disabled students have been excluded and isolated within the present education system. An inclusive school caters for a non discriminative environment for disabled or special needs children where it leads to main goals of education like social cohesion and social justice. The focal aim of inclusive education system is to ensure the right of the disabled and special needs students to study in mainstream schools where the right to education has been promoted through not marginalizing the disabled students. The current education system should transformed to cater diversity of students' learning needs despite of social, cultural and physical differences and enhancing learning motivation, adaptability and abilities. The study aims at the exclusion of educational opportunities of disable students and the primary data was collected through case studies and the additional data was collected through diverse secondary sources. The findings of the study ensures implementation of inclusive education policy which has to be reconstructed using homogenous approaches, which develop an education model considering diversity of needs, abilities and identities where teaching-learning process comprises flexibility and adaptability to cater diverse needs of student population.
\end{abstract}

Keywords: Social exclusion, Inclusive education, Social cohesion, Social justice, Homogenous approaches

\section{Introduction}

Learning disabilities are significant difficulties in the acquisition and use of listening, speaking, reading, writing or mathematical abilities due to an unknown factor that impacts the brain's ability to receive and process information. "Dyslexia is a specific learning disability that is neurobiological in origin. It is characterized by difficulties with accurate and/or fluent word recognition and by poor spelling and decoding abilities. These difficulties typically result from a deficit in the phonological component of language that is often unexpected in relation to other cognitive abilities and the provision of effective classroom instruction. Secondary consequences may include problems in reading comprehension and reduced reading experience that can impede growth of vocabulary and background knowledge.” (International Dyslexia Association, 2002) Dyslexia is a language disability, affecting reading, writing, speaking and listening. It is a dysfunction or impairment in the use of words. Consequently, relation with others and performance in every subject in school can be affected by dyslexia. The most common learning disabilities to affect Sri Lankan children are reading disorders, disorder of written expression, dyscalculia and a nonverbal learning disability. The simple sentence 'The bat and ball were on the mat' may look like 'Teh dat anb dall were no teh mat' to a child suffering from a learning difficulty known as dyslexia. According to the WHO, 10.6\% of school-aged children in Sri Lanka suffer from special 
needs assistance due to various learning disabilities. Despite the significant number of children with learning disabilities in Sri Lanka, many cases are misdiagnosed with a lack of information, education and support as leading factors for this. $70 \%-80 \%$ of children with a learning disability have a reading disorder known as developmental dyslexia. Dyslexia is used to describe a condition in which children cannot read fluently and have trouble making sense of what they are reading. A foundation of education is learning to read and if reading problems in Sri Lanka are not diagnosed early, it will impact most aspects of education as well as weaken a child's self-esteem.

Ensuring the Right to Education for ALL

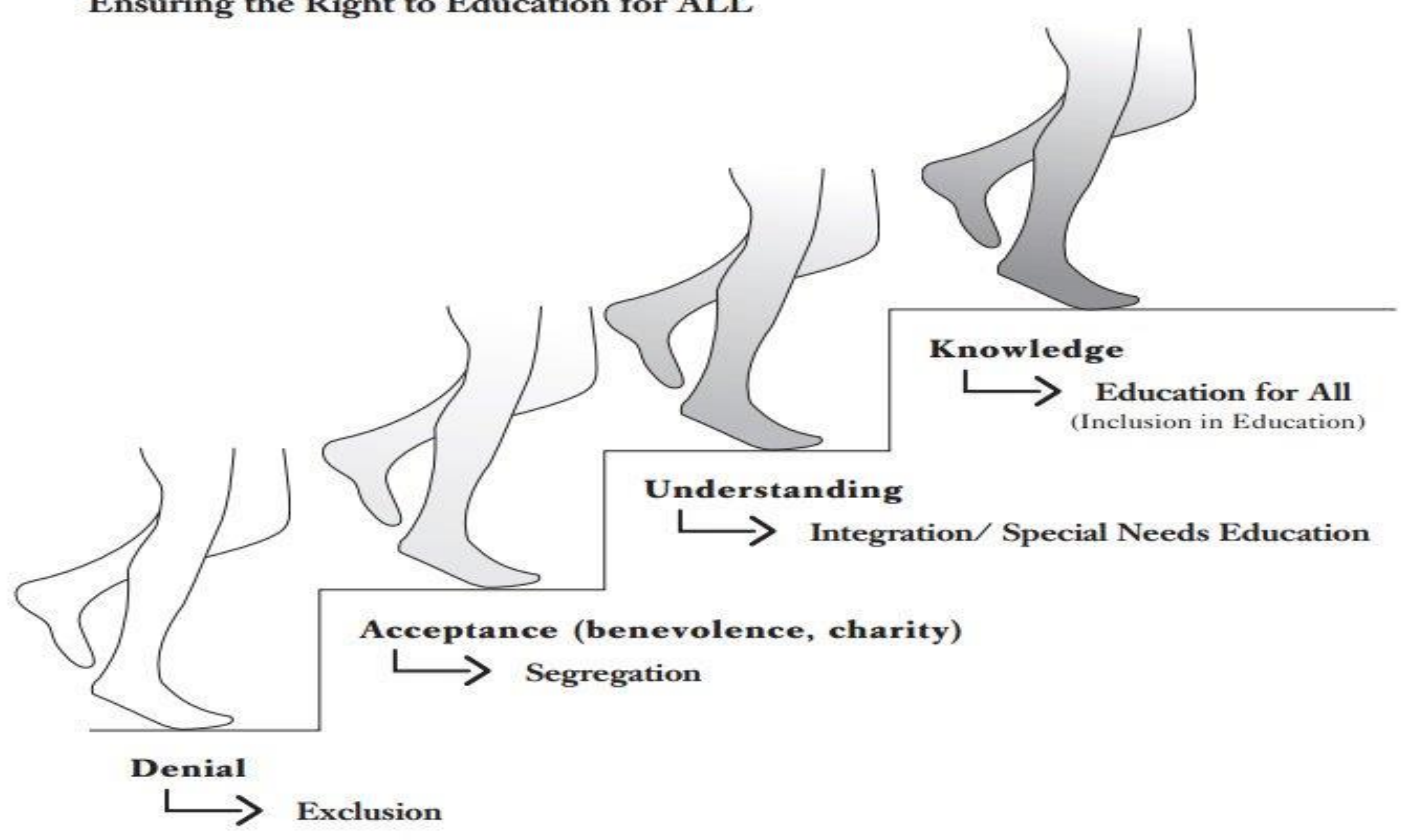

Figure 01: Steps from exclusion to inclusion

As the Figure 01 explains the steps from exclusion to inclusion, earlier the disabled children were totally excluded from the educational settings but step by step starting from the concept of acceptance they were identified as an important target group with the inspiration of charity. Then the concept of understanding explains the integration of disabled children with the education opportunities through special needs education. The final step explains the concept of education for all or inclusion of disabled children within the normal education system. Inclusive education is more effective and it actually caters for the exact meaning, the right to education of disabled children. Inclusive education is included in the current education policy of Sri Lanka but there are immense loop holes when it comes to the implementation of inclusive education policy. This research was conducted to examine the exclusion of education opportunities encountered by primary school students with learning disabilities specifically dyslexia, the implementation of inclusive education through National Education Policy and the loopholes of inclusion which leads to exclusion. The main objective of this study is to identify challenges faced by dyslexic students and their exclusion within inclusive education opportunities due to those challenges. The first sub objective of this study is to examine the nature of implementation of National Education Policy and to suggest recommendation for better execution of inclusive education opportunities for dyslexic students within the school systems and the second sub objective is to identify the school social work intervention to implement friendly inclusive education environment for learning disable students in school settings. 


\section{Methodology}

The study was carried out using qualitative narrative case study method as the primary data collection method with in-depth interviews and semi structured interviews. Through purposive sampling method 15 participants (03 male students and 03 female students from the primary section of an urban government school who have diagnosed with dyslexia between the ages 8-10 through school counsellor, 04 class teachers and five parents were selected as the sample with their consent. Direct Observation was also used as a primary data collection method and medical, case and school reports were used as the secondary data collection methods.

Table 01: Description of the sample

\begin{tabular}{|c|c|c|c|c|c|}
\hline $\begin{array}{l}\text { Name (Changed } \\
\text { Real Names) }\end{array}$ & Age & Gender & Grade & Ethnicity & $\begin{array}{l}\text { Family } \\
\text { Background }\end{array}$ \\
\hline Mahesha & 10 & Female & 5 & Sinhalese & Only child \\
\hline Dilumi & 09 & Female & 4 & Sinhalese & $\begin{array}{l}2^{\text {nd }} \text { child has an } \\
\text { elder brother }\end{array}$ \\
\hline Ann & $08+$ & Female & 3 & Christian & $\begin{array}{l}3^{\text {rd }} \text { child and has } \\
\text { two elder sisters }\end{array}$ \\
\hline Roshan & $09+$ & Male & 4 & Sinhalese & $\begin{array}{l}2^{\text {nd }} \text { child and has } \\
\text { an elder sister }\end{array}$ \\
\hline Akmal & 10 & Male & 5 & Muslim & $\begin{array}{l}2^{\text {nd }} \text { child and has } \\
\text { an elder brother } \\
\text { and younger } \\
\text { sister }\end{array}$ \\
\hline Ravi & 08 & Male & 3 & Tamil & $\begin{array}{l}\text { Eldest and has } \\
\text { two younger } \\
\text { sisters }\end{array}$ \\
\hline
\end{tabular}

The Table 01 explains about the sample details and the real names of all the participants have changed due to confidentiality and ethical reasons. The study consists of participants from different ethnic groups and both female and male participants to ensure the ethnic and gender equality. The qualitative data was analysed through a step by step process identifying emerging themes clustering those by concepts. The emerging themes were labelled with children's as well as researcher's words. All the case studies are discussed hereunder.

\section{Case Studies}

\section{Case 01}

Mahesha is a 10 year old Sinhalese girl studying in grade five. She is the only child in the family and she is diagnosed as a dyslexic child when he was in grade two. Her parents were unable to identify his condition in the initial period but later on they were able to understand her difficulties in reading. Since she is the only child in the family she was facing lots of issues due to his condition. She uses to get bullied from his peer groups due to not be able to read the text book. She was marginalized within her peer group due to her academic inabilities. 


\section{Case 02}

Dilumi is a 09 year old mischievous youngster who has an elder brother and she is from a Sinhalese family who never showed any outward signs of incompetence, except in writing. But then she was only five years old, the age for learning through guidance. As the years passed, however, it became harder for her to grasp the learning techniques. Her performance in class deteriorated and she was very poor in her academics. It did not take long for Dilumi's parents to realize what was wrong with their energetic daughter. She is suffering from dyslexia and not only had a problem with writing but also with reading, spelling, and mathematics. Dyslexia is a problem many parents prefer to ignore, hoping against hope that their child will be able to settle down in school despite learning difficulties during the first few years. But such parents only drive their kids from reality.

\section{Case 03}

Ann is a 08 year old Christian girl who is studying in grade three and she is the third child and had two elder sisters. When it comes to reading the text book, she either read in reverse or skips lines and gets the letters mixed up. Placing is also a big problem for her. If she was asked to write the date on the left hand corner of the page, she writes it opposite or at the bottom. Her teachers use to complain about her low performance to her parents but since both her parents are engaged in private sector jobs, they didn't had much time to give much importance to Ann's school work. Both elder sisters use to help her do her home work and take care of her most of the times with the help of their grandmother.

\section{Case 04}

Roshan is a 09 year old boy from a Sinhalese family and has an elder sister. He uses to have difficulties in reading and writing from his early childhood. His parents were not willing to accept that he is having difficulties and they always use to force Roshan to study rather than understanding his condition. He is interested in computer games and not much interested in his academics thus he often gets scolding from his parents due to his less interest in studies. Moreover his parents use to praise her elder sister because she is really good in her academics and most of the times they use to compare him with his sister which lead him to feeling of inferiority.

\section{Case 05}

Akmal is a 10 year old Muslim boy and has a younger sister and an elder brother. He is dyslexic from his early childhood. Even during his pre-school he had lots of problems when it comes to reading and understands the letters. His parents were not ware about his condition and didn't know much about his dyslexic condition. He needed a special attention from the school teachers to overcome his inabilities but they are unable to give him special care and attention due to hectic work schedule and vast syllabus.

\section{Case 06}

Ravi is a 08 year old Tamil boy who is the eldest in his family and has two younger sisters. His academic performance is very poor due to his dyslexic condition. He uses to be the last from his grade one. He is unable to follow simple instructions and due to these difficulties he was bullied from his peers constantly. His parents knew about his inabilities but they were not much interested to help him in his studies and understand his dyslexic condition.

\section{Results and Findings}

The direct narrative quotes of the student participants were used as the primary data collection in this study. The table 02 demonstrates the direct narrative quotes of students. 
Table 02: Narrative quotes of students related to themes

\begin{tabular}{|l|l|}
\hline Themes & Narrative quotes of students related to themes \\
\hline 01) Self Esteem & $\begin{array}{l}\text { "I am not good at reading out loud. I'm too slow and it } \\
\text { doesn't come out right." } \\
\text { "I get my P, D and B different, but my younger sister } \\
\text { can easily understand those." } \\
\text { 02) Bullying }\end{array}$ \\
\hline "I work but nothing happens." \\
\hline "My friends were calling me stupid." \\
"My friends say I am a fool."
\end{tabular}

The above narrative quotes of participants revealed that each student participant's faces difficulties, challenges or feelings of sadness when adjusting within the school environment. There were significant issues like bullying, low self esteem, isolation among peers, and low academic performance and one to one attention requirement from their class and subject teachers. Moreover the in-depth interviews with dyslexia students, it revealed that their self esteem was very low due to their learning disability. The semi structured interviews with parents revealed that most of them were not aware about learning disabilities but when their child was diagnosed as a child with dyslexia they tend to gather much information about the disability. The semi structured interviews with teachers reveals they are not much aware about the learning disability dyslexia due to that they were unable to understand the difficulties and challenges faced by dyslexic students. Though there was a school counsellor in the school there was no support system available for dyslexic students within the school system. It was visible through direct observation that the dyslexic students are often humiliated and isolated within their class room settings and the class room settings are not friendly towards dyslexic students. Some parents use to compare their non dyslexic child with dyslexic child and that actually leads the dyslexic child more inferior feeling and low self esteem. The findings of the research study reveals that most of the times Sri Lankan education system doesn't provide a student friendly school environment for dyslexic students though the inclusive education policy is a major component of national education policy.

\section{Conclusion}

The research study reveals that all the though all the dyslexic students were given an opportunity to study without any discrimination according to the inclusive education policy, most of the times they were excluded within the education system due to lack of support system within the schools for their disability condition. The students with dyslexia need to be provided with treatment programs that employ more than one academic skill. 
Also, these programs will be based on the positive interaction between students and teacher, based on performance of students and receiving feedback from the teacher. Additionally, the students can be educated through computer-based programs related to the literacy of reading and writing. The use of recent teaching methods and modern programs especially that related to the use of senses to give students with dyslexia the opportunity to recall and recognize words and sentences. In order to be able to teach, as far as possible, according to each child's educational needs, it is essential to see him or her as a whole person, complete with individual strengths and weaknesses. An understanding of the pupil's specific difficulties, and how they may affect the student's classroom performance, can enable the teacher to adopt teaching methods and strategies to help the dyslexic child to be successfully integrated into the classroom environment. Class teachers dealing with dyslexic children need to be flexible in their approach, so that they can, as far as possible, find a method that suits the pupil, rather than expecting that all pupils will learn in the same way. Above all, there must be an understanding from all who teach them, that they may have many talents and skills. Their abilities must not be measured purely on the basis of their difficulties in acquiring literacy skills. Dyslexic children, like all children, thrive on challenges and success. At last it is essential to keep on investigating the needs of vulnerable young individuals with learning difficulties, to identify best possible ways to transform their educational experiences to a path to success.

\section{Recommendations}

Parents play a significant role in helping manage their child's learning disability. Thus, it is important to aware them that having learning disability like dyslexia does not mean it is a sickness but a challenge that the family must work together with time, persistence and patience. A special training should be given to Sri Lankan teachers to identify dyslexia and work with dyslexic and other learning disable students. Moreover the peer coaching is a concept which we should introduced within our school settings to minimize the negative interrelationships of dyslexic students and their peers and to overcome the academic barriers of dyslexic students. The traditional teaching methods should change and the teaching strategies as well as attitudinal change of teachers is needed to generate child-centred conducive learning environment. The existing inclusive education policy should re formulate to create a child-friendly learning environment for students with dyslexia and other learning disabilities. School social workers should be appointed in schools to identify issues related to students because social workers can bring necessary changes in the system and also in creating and implementing policies in order to cater the needs of students with learning disabilities.

\section{References}

Reid.G, 2009, Dyslexia: a practitioner's handbook. 4th ed. West Sussex: John Wiley and Sons.

Girod.C, 2001, Learning disabilities (diseases and disorders) 1st ed. San Diego: Lucent books.

Openshaw.Linda, 2008, Social Work in Schools, Principles and practice. London : Guilford Press.

Hornsby.B, 1996, Overcoming Dyslexia. New Jersey: Ebury Press.

Snowling M.J, 2000, Dyslexia. 2nd ed. West Sussex: John Wiley and Sons.

Swanson HL, Harris KR, Graham S, 2003, Handbook of Learning Disabilities. 1st ed. New York: Guilford Press.

http://nec.gov.lk/category/policies/on 25/08/2017 at 8.30am 